\title{
The value of voting rights in Italian cooperative banks: a quasi-natural experiment
}

\section{Voting rights in Italian cooperative banks}

\author{
Marco Botta \\ Universita Cattolica del Sacro Cuore, Milano, Italy and \\ Università degli Studi dell'Insubria, Dipartimento di Diritto, Economia e Culture, \\ Como, Italy, and \\ Luca Vittorio Angelo Colombo \\ Università Cattolica del Sacro Cuore, Dipartimento di Economia e Finanza, \\ Milano, Italy
}

\begin{abstract}
Purpose - It is widely believed that deviating from the "one share-one vote" principle leads to corporate inefficiencies. To measure the market appraisal of this potential inefficiency, this study aims to analyse the market reaction to a change from the "one head-one vote" to the "one share-one vote" mechanism by means of a quasi-natural experiment: a 2015 Italian reform forcing all listed cooperative banks to transform into joint-stock companies.

Design/methodology/approach - To investigate the market reaction around the regulatory change, this study uses both a traditional event study and a novel methodology based on the synthetic control method as well as on Bayesian statistical techniques.

Findings - This study estimates the market valuation of the effects of the governance change around the event date being equal to a cumulative average increase in market value of about 14 per cent using an event study methodology, and of about 13 per cent using Bayesian techniques.

Originality/value - This study provides evidence on the fact that the voting mechanism significantly affects the market values of companies. The study also introduces a novel statistical technique that can be extremely useful in analysing single-firm event studies.
\end{abstract}

Keywords Corporate governance, Corporate voting, Bank regulation, Voting premium

Paper type Research paper

\section{Introduction}

Italian banks are established either as joint-stock companies (Società per Azioni) or as cooperative banks. The latter are further divided in two categories, Banche Popolari and Banche di Credito Cooperativo ("BCC"). According to the 1993 Italian Banking Act (Testo Unico delle Leggi in Materia Bancaria e Creditizia, commonly shortened with the acronym TUB), the Banche di Credito Cooperativo have a governance closely resembling that of typical mutual banks. Namely, their governance is based on the "one head-one vote" mechanism, they have to operate mainly with their members, they face restrictions on the distribution of

\section{JEL Classification - G34, G38, K22}

(C) Marco Botta and Luca Vittorio Angelo Colombo. Published by Emerald Publishing Limited. This article is published under the Creative Commons Attribution (CC BY 4.0) licence. Anyone may reproduce, distribute, translate and create derivative works of this article (for both commercial and non-commercial purposes), subject to full attribution to the original publication and authors. The full terms of this licence may be seen at http://creativecommons.org/licences/by/4.0/legalcode

The authors would like to thank for their helpful comments all conference participants at the 15th Workshop on Corporate Governance held in Brussels on November 5th-6th 2018 at the EIASM - European Institute for Advanced Studies in Management, as well as seminar participants at the Laboratorio di Analisi Monetaria, held on June 27th at the Associazione per gli Studi di Banca e Borsa in Milan, Italy.

Received 8 July 2019 Revised 3 November 2019 Accepted 1 December 2019

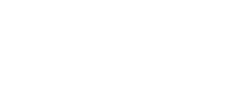

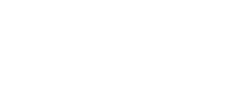


MF

46,7

862

earnings and they are allowed to operate within specific geographic areas only. Furthermore, they cannot transform into joint-stock companies. The Banche Popolari, instead, have a hybrid nature. On the one hand, their governance is that typical of cooperative banks, characterised by the adoption of the "one head-one vote" mechanism, as well as by the presence of limits to individual holdings and the requirement of board approval for the admission of new members. On the other hand, they are in many respects similar to jointstock companies. For instance, in terms of earnings distribution, share listing on financial markets, the possibility of transforming into joint-stock companies, the freedom to expand geographically without constraints or to freely operate with non-members. Moreover, the approval of new memberships is only required for gaining voting rights. Non-members may hold shares enjoying property rights (i.e. the right to receive the corresponding share of distributed earnings), although not voting rights. In other words, the Banche Popolari are governed as cooperative banks, but they operate in the market as commercial banks.

On the 20 January 2015, the Italian government passed a decree law requiring the Banche Popolari with total assets exceeding $€ 8 \mathrm{bn}$ to transform into joint-stock companies within the next 18 months. The stated goal of the decree was to strengthen the Italian banking sector, by making the Banche Popolari more attractive to outside investors through the removal of the "one head-one vote" system, which has prevented hostile takeovers, easier access to equity investments and the removal of inefficient boards. This government intervention provides an ideal test-bank to assess the impact on market values of the shift from a "one head-one vote" to a "one share-one vote" mechanism. While the assignment of individual banks (the involved Banche Popolari) to the "treatment" group is not entirely random, one can still run a "quasinatural experiment" exploiting the largely unanticipated regulatory change to assess the value of an imposed shift to proportional voting rights. To this end, we compute the cumulative abnormal returns for all the listed banks affected by the government intervention using a variety of return models and event windows. We rely both on available public information and on the observed distribution of abnormal volumes around the date of the announcement to properly define the event window.

In addition to an analysis based on the classical event studies methodology, we investigate the effects of the government intervention by means of the "synthetic control" method, based on a Bayesian statistic approach. In particular, we apply Brodersen et al.'s (2015) estimation procedure to infer the causal impact of the government announcement through a Bayesian structural time-series analysis. To the best of our knowledge, there are no other applications of this new methodology in corporate finance. One of its key advantages is that it does not rely on a control group in the conventional sense, but it adopts a general time-series model based on trend extrapolation and relevant covariates to forecast what would have happened to the series of interest (the stock returns of each Banca Popolare in the days following the government announcement) in the absence of the market intervention under investigation. This new methodology allows us to circumvent an unavoidable limitation of our analysis when running a classic event study, namely, that the government decree applies to seven listed banks only.

Our work contributes to the literature on corporate governance and banking regulation by assessing quantitatively the difference in share value induced by the usage of the "one headone vote" system rather than of the "one share-one vote" system in large cooperative banks. Indeed, the government intervention provides for a unique opportunity to directly estimate the value of voting rights, while so far, the existing literature on the topic could only estimate it indirectly, either by comparing the market prices of different classes of shares within the same company or by analysing price conditions in trades concerning control blocks of shares.

The unique nature of the event (i.e. a legal intervention substantially affecting banks' governance) offers interesting insights. We find that the government announcement had a significant impact on the returns of the Banche Popolari involved in the reform. Using an event study methodology, we estimate an average cumulative abnormal return for the 
treatment group (the Banche Popolari involved in the reform) of 19 per cent over a $[-2,+1]$ event window and of 21.6 per cent over a $[-2,+20]$ event window. As for the control group (composed of the Italian banks incorporated as joint-stock companies), we find a cumulative abnormal return of 2.4 per cent in the shorter event window and of 4.1 per cent in the longer one. Overall, this leads us to estimate that the governance change has generated an increase in the value of the Banche Popolari of around 15 per cent in the days around the announcement. This value can be taken as a measure of the market appraisal of voting rights. When relying on Bayesian techniques, we obtain similar estimates for the effect of the government announcement: looking in particular at the shorter event window, the estimated impact for the treatment group is always statistically significant, ranging between 7 and 18 per cent.
Voting rights in Italian cooperative banks

\section{Related literature}

A dominant view in the financial literature is that deviations from the "one share-one vote" principle induce concentrated control. On the one hand, this may allow for lower monitoring and capital allocation costs. On the other hand, it may induce both microeconomic distortions - due to entrenched managers, control rights disproportionate to the ownership stakes, inefficient investment decisions - and macroeconomic misallocation of resources (that ends up derailing growth opportunities). Morck et al. (2005) survey the effects that concentrated control produces both at the micro and macro level, reporting that highly concentrated control leads to distorted capital markets, limiting investments towards innovation and inducing a preference for rent-seeking activities, which in turn lowers economic growth. Burkart and Lee (2007) provide a more mixed view on the merit of the "one share-one vote" principle. On the one hand, they highlight that giving shareholders' voting rights in proportion to their investment stake ensures economic efficiency. Deviations from the "one share-one vote" principle may instead induce controlling shareholders to adopt suboptimal behaviors, due to a wedge between the benefits they may extract from controlling the company and the cost they pay in terms of lower firm value. On the other hand, they stress the costs associated with the "one share-one vote" principle. In particular, issuing equity is more costly for private firms, as owners suffer a reduction in control rights due to dilution, which may lead to the emergence of inefficient capital structures (see, e.g. Harris and Raviv, 1988). Moreover, it exacerbates free-riding in the takeovers of dispersed firms, thus increasing the costs of hostile acquisitions. This may in turn discourage investors from acquiring controlling stakes and reduce the efficiency of the market for corporate control. Overall, then, the one share-one vote principle may end up increasing the costs of control exactly for those majority shareholders it wants to protect.

A large stream of empirical research measures the value of voting rights in listed companies (see Adams and Ferreira (2007) for a comprehensive survey). Levy and MacKinlay (1983) investigate the Israeli market where firms can issue dual-class shares with identical characteristics, but for voting rights, finding that for many firms, the voting premium exceeds 100 per cent, and the average premium is 45.5 per cent. Zingales (1994) estimates the premium at which ordinary shares trade compared to preferred non-voting shares in the Italian stock exchange. He finds that voting shares, despite having inferior dividend rights, trade at an average premium of 82 percent above non-voting shares. When adjusting this estimate to take into account that non-voting shares are also entitled to a higher dividend, the average premium rises to more than 90 percent. Nenova (2003) measures the value of voting rights in companies from 18 different countries. She finds that the average value of controlblock votes ranges from -2.88 per cent in Hong Kong up to 48 per cent of firm value in South Korea. Dyck and Zingales (2004) analyse the sales of controlling blocks for companies from 39 different countries, finding an average premium for acquiring control of 14 per cent, with large differences between countries (ranging from -4 to 65 per cent of firm value). Kind and 
Poltera (2013) adopt yet a different approach to measure the value of voting rights, by extracting it from the market prices of American-style call options written on the stocks of the corresponding company. They find that the value of voting rights for European companies is on average 0.37 per cent of the share price, with a significant increase in the months when ordinary or extraordinary shareholders' meetings are held. Their estimate is much smaller than suggested by the studies based on the price differential between shares of different classes, or for trades concerning control blocks.

Another relevant strand of literature focuses on the interconnections between ownership structure and firm value. Thomsen et al. (2006) study the relationship between blockholder ownership and firm value, finding that in Continental Europe (but not in the UK and in the USA), high blockholder ownership produces a significant and negative effect on firm value and on profitability. This may depend both on the relatively high average level of blockholder ownership in Europe and on the opportunities that large blockholders have to use their power to extract private benefits at the expenses of minority shareholders. Schmid (2009) analyses the relationship between a firm's ownership structure and its value by looking at Swiss firms with a dual-class shares structure. He finds that the dual-class structure induces a significant discount in firm value, which increases with the degree of separation between voting and cash flow rights.

A common feature of the literature surveyed above is that it investigates the deviations from the one share-one vote principle induced by preferred shares, dual-class shares, the presence of blockholder ownership and similar forms of separation between ownership and control that aim at empowering a large shareholder to increase their control power over the minority shareholders of a company. The nature of the problem we focus on here is different. The Banche Popolari do not have dual-class shares, nor preferred non-voting shares, nor control pyramids or other instruments for separating voting rights from ownership. Instead, their governance rule establishes that voting rights are completely disconnected from the size of ownership: any shareholder is entitled to one vote, and one vote only, whatever the number of shares he/she holds. In other words, the governance structure is exogenous, in that it is not the result of existing shareholders' decision to separate ownership and control. Once a bank is established as a Banca Popolare, the rules concerning voting rights are entirely defined by the law. This peculiarity makes the problem at hands hardly comparable to those typically addressed by the literature on voting rights. Notwithstanding, as the government reform induces a realignment between ownership and voting rights, taking stock from the literature on voting rights, one should expect the market value of the affected banks to increase following the announcement.

Our paper is also related to the literature investigating the role of governance rules as determinants of banks' profitability. Gorton and Schmid (1999) examine the efficiency of Austrian cooperative banks, focusing in particular on the effects of the degree of separation between ownership and control and bank performance. They find that, on average, the doubling of the number of cooperative members (their proxy for the degree of separation between ownership and control) reduces the returns on assets by a factor seven. Casu and Molyneux (2003) - focusing on banks located in France, Germany, Italy, Spain and the UK between 1993 and 1997 - find that commercial banks do not display higher levels of efficiency than savings and cooperative banks. On the contrary, Iannotta et al. (2007) focusing on the performance of large banks in 15 European countries - find that cooperative banks have lower profitability (but also better loan quality and lower asset risk) than joint-stock company banks. Overall, it emerges that large cooperative banks are characterised by a lower efficiency than their joint-stock company counterparts, possibly as a consequence of both inefficient management and more prudent investment policies. Girardone et al. (2004) study the determinants of bank efficiency for Italian banks during the period 1993-1996, finding that (in that period) cooperative banks (both Banche Popolari 
and Banche di Credito Cooperativo) were performing better, with higher levels of Xefficiency[1] and were better able to exploit cost reduction in terms of economies of scale. Ferri et al. (2014a) analyse whether the lending policies of cooperative and joint-stock company banks respond differently to monetary policy changes. They find that cooperative banks reduce loan supply less than joint-stock company banks following a monetary policy contraction, hence smoothing its impact on lending. Cooperative banks can, therefore, play an important role in mitigating the volatility of loan supply. Ferri et al. (2014b) show, instead, that cooperative banks have been characterised by a lower credit rating than joint-stock company banks before the global financial crisis, suffering, however, a lower reduction in rating during the crisis. This suggests that cooperative banks have been more resilient during the crisis, likely because their ownership structure induced less risk-taking. Taken together, these two results indicate that cooperative banks play an important role in the economy, being better able than their joint-stock company counterparts to mitigate the impact of the business cycle on credit supply, at the same time not suffering an excessive credit rating deterioration. Ferri et al. (2015) conclude that both ownership structures have their merits. Joint-stock company banks experienced higher profitability before the crisis, while cooperative banks had higher loan quality andalthough to a lesser extent - higher cost efficiency, both before and during the crisis. This, however, does not hold true for the larger and more loosely integrated cooperative banks (as the largest Italian Banche Popolari), which do not appear to be more cost efficient than jointstock banks, suggesting that the cooperative structure may no longer be the most efficient one when size becomes large. Focusing on risk rather than profitability, Sharpe (1991) examines the effects of ownership structure on the capital management of "building societies" located in the Australian State of Victoria. He finds that privately owned "societies" adjust capital faster than mutually owned ones, and that mutually owned "societies" have little capacity to modify their capital ratios in the short or medium term. This, in turn, indicates that mutually owned "building societies" could incur in serious problems when having to adjust their capital to comply with regulators' prudential requirements. Overall, the literature focusing on the effects of governance rules on profitability and risk-taking suggests that the market should react positively to the announcement of a reform of voting rights like that approved by the Italian government in 2015 , expecting an increase in the efficiency and profitability of the banks involved, and an improved access to equity capital or merger deals.

In a methodological perspective, due to the limited number of banks involved, the event studies we develop in this paper resemble the so-called "single-firm event studies" involving only one individual company and one single event date. The issue of investigating abnormal returns in single stocks on a specific event date is typical in court litigations on market manipulation, securities fraud or information abuses[2]. The main problem in single-firm event studies is how to build a reliable statistical inference, given the limited number of observations available. Gelbach et al. (2013) question the validity of the standard event-study approach in this context and propose an alternative test - that they call "SQ" test - for achieving a valid inference for the event effect and reducing the risk of committing Type I errors. Rather than using the normal or Student's $t$ distribution as is typically done in event studies, the SQ test relies on the sample quantiles of the estimated excess returns distribution in the estimation window to obtain the critical values for the effect of the event. In our analysis, we adopt both the traditional $t$-test and SQ test when testing for the statistical significance of the estimated abnormal returns. Abadie and Gardeazabal (2003) propose yet an alternative methodology, the "synthetic control" method, as a means to better construct a valid control group to be compared with the treatment group. This method is based on the construction of a synthetic counterfactual to the true outcome of the analysed time series by appropriately weighting the elements included in the control group. The counterfactual is 
$\mathrm{MF}$

46,7

then used to determine how the variable of interest would have evolved had the event not occurred. Brodersen et al. (2015) further develop the synthetic control method, by using Bayesian techniques for processing the available information to optimally choose the weights to be used in the construction of the synthetic control. We rely on this methodology in the last part of the paper.

\section{Data description}

All data on prices, volumes, outstanding shares, floating shares, interest rates and exchange rates are obtained from Datastream. All accounting data are taken from Worldscope. Ownership data are from the Consob database on share ownership in listed companies[3].

Our "treatment" group includes all the listed Banche Popolari affected by the reform: Banca Popolare di Sondrio ("BPS"), Unione di Banche Italiane ("UBI"), Credito Valtellinese (“CV”), Banca Popolare dell'Emilia Romagna (“BPER”), Banca Popolare di Milano ("BPM”), Banco Popolare ("BP”) and Banca Popolare dell'Etruria e del Lazio ("PEL”). Three more banks - Banca Popolare di Vicenza ("BPVI"), Veneto Banca ("VB") and Banca Popolare di Bari were affected by the reform, but were not listed, implying that their market prices could not be retrieved. Moreover, although these banks regularly offered the possibility to buy and sell their shares in private negotiations with the bank itself, we could not retrieve an appropriate (in terms of length and frequency) time series to analyse the prices at which internal transactions occurred[4].

To check whether the observed excess return can be unambiguously assigned to the effects of the reform rather than to some other confounding events, we construct a "control" group of banks not directly affected by the reform itself. Note that no other Banche Popolari than those involved by the reform were listed on the stock market at the time of the announcement. Hence, there are no other listed Banche Popolari that were not affected by the regulatory change. Unfortunately, it also turns out to be impossible to retrieve the prices at which unlisted Banche Popolari bought and sold their shares through the self-placement mechanism around the time of the announcement[5]. We deal with these data limitations by constructing a control group that encompasses (almost) the entire population of listed Italian banks incorporated as joint-stock companies[6].

The event date around which our study is centered is 21 January 2015. The government announcement was officially made on 20 January 2015, after market closure[7]. Therefore, the market could have traded on the official news of the reform only from 21 January 2015, onward. However, rumors already circulated in the market since at least 19 January 2015, when Reuters (during trading hours) published a press release stating to have seen a draft of a decree law containing provisions aimed at abolishing the one-head one-vote voting system in Banche Popolari[8]. During his parliamentary hearings on 11 February 2016, the Consob President stated that the date on which the market could have "reasonably known" the government intentions on the reform was 16 January 2015, when - at closed markets - the prime minister announced a reform of the law concerning cooperative banks[9].

Based on the timing of relevant information, we construct our estimation window by first eliminating the 30 trading days before the official announcement, and then by looking at prices and volumes in the previous 120 trading days. Finally, we build an event window that runs from 20 trading days before to 20 trading days after the event. It is important to note that we only have a $[-20,+15]$ event window for PEL, because its shares have been suspended from trading on 13 February 2015, following a Bank of Italy inspection finding evidence of a severe deterioration in the bank's financial position and prompting the appointment by the treasury of an extraordinary commissioner replacing the board of directors[10]. The required market data have been retrieved for the period between 30 December 2012 and 18 February 2015. 
We use the DJ Eurostoxx index for measuring market returns and the Eurostoxx Value, Eurostoxx Growth, Eurostoxx Small and Eurostoxx Large indexes to build Fama and French (1992) size and growth daily factor returns in the Euro Area. The daily return on the size portfolio is obtained as the daily return of the Eurostoxx Small minus that of the Eurostoxx Large index, while the daily return on the growth portfolio is obtained as the daily return on the Eurostoxx Value minus that on the Eurostoxx Growth index. Finally, we use the spot Euro-US\$ exchange rate to build an exchange rate risk factor and the spread between ten-year Italian Government Bonds and ten-year German Government Bonds as an interest rate risk factor.

Finally, we collect data concerning TIER1 ratios under stressed macroeconomic scenarios from the results of the "2014 EU-wide stress test" and data on non-performing loans from the "2015 EU-wide Transparency Exercise", both coordinated by the European Banking Authority in cooperation with the European Commission, the European Systemic Risk Board, the European Central Bank and the competent authorities from all relevant national jurisdictions.

To put the reform of Banche Popolari in the right perspective, it is important to note that such reform is part of a broader agenda aimed at reinforcing the Italian banking system and making it more appealing to international investors. On 22 April 2015, banking foundations - controlling the largest Italian banks as a result of the privatisation process of the 1990s - entered a process of self-reform signing a protocol with the Italian Treasury Minister. The protocol provides for the diversification of foundations' investments, stating that a foundation cannot concentrate more than 33 per cent of its capital in a single company. It also restricts foundations' possibilities to rely on borrowing, except in the event of temporary, limited needs for liquidity and it constrains the use of derivatives for hedging purposes. Furthermore, it requires foundations to commit to a high level of transparency in their activity and in their financial reports and to sever the ties between local political forces and foundations' management. In addition to the self-reform of banking foundations, the Decree 18/2016 outlined a reform of the Banche di Credito Cooperativo, aimed at reducing the fragmentation of the sector and the structural weaknesses associated to the business model of these banks. The 2016 reform acknowledges the role of BCC in serving local communities, at the same time introducing governance requirements aimed at increasing the quality of the provided services and at simplifying internal organisation. The reform requires all BCC to join a Cooperative Banking Group, to enhance both competitiveness and stability over the long run. Finally, Decree 59/2016 introduced a set of measures for simplifying compliance and streamlining credit recovery procedures[11].

It is also worth noting that overall the reform of the Banche Popolari has been fiercely opposed by some of the shareholders of the involved banks. In particular, a group of minority shareholders of BPS - then followed by shareholders of other Banche Popolari and Banca popolare di Bari in particular - appealed against the reform, claiming that parts of it would violate the Italian Constitution. The appeal has been rejected by the Council of State, Italy's highest administrative court, after having received a ruling on the matter from the Constitutional Court. However, the same group of shareholders has further appealed on the compatibility of the reform with relevant European rules to the Council of State, which stated that it would not be able to decide on the matter before a ruling of the European Court of Justice. In the meantime, all other Banche Popolari have transformed into joint-stock companies, and in January 2017, two of them (BPM and BP) decided to merge and create a new banking group, Banco BPM, in the form of a joint-stock company bank. As a result, of the ten original Banche Popolari that were subject to the reform, one has been resolved soon after the announcement, two have been transformed into joint-stock companies but eventually have been declared insolvent and wound up by the government and two are still waiting for a final decision on the compatibility of the reform with Italian and European rules before transforming. The other five have complied with the reform within the original deadline, with
Voting rights in Italian cooperative banks 
$\mathrm{MF}$

46,7

two of them having subsequently merged into a new banking group, while the remaining three are still operating as standalone banks.

\section{The event study}

\subsection{Abnormal volumes}

We first analyse trading volumes around the event date to detect abnormal market activities and define the event window to be used for calculating abnormal returns[12]. We measure trading volumes as the log of the ratio between the nominal volume traded in the day divided by the total number of floating shares, obtained by multiplying the number of outstanding shares times the portion of shares that are floated in the market. We use log volumes rather than absolute volumes to make the distribution symmetric. In fact, absolute volumes do not exhibit the properties of a normal distribution, being highly skewed and with fat tails, while log volumes closely resemble the properties of a normal distribution.

We then compute the average log volumes over our estimation window and measure the abnormal volumes induced by the announcement according to the equation:

$$
\left(\Phi_{i, t}\right)=\phi_{i, t}-\phi_{i}
$$

where $\Phi_{i, t}$ denotes abnormal volumes for bank $i$ at time $t$, $\phi_{i, t}$ denotes trading volumes for bank $i$ at time $t$ and $\phi_{i}$ indicates the arithmetic mean of trading volumes for bank $i$ during the 120-day estimation window. The difference in Eqn (1) between daily log turnover during the event window and the average over the estimation window is the measure of abnormal trading volume near the announcement. We test for the statistical significance of the daily abnormal volumes assuming that they follow a normal distribution with mean equal to zero and variance equal to that of the trading volumes over the estimation window, obtain the corresponding $p$-value for the null hypothesis that they are equal to zero. Table I reports our results. For all the banks in the treatment group, we find statistically significant abnormal volumes starting from two days before the event date, confirming that the rumors reported in the news significantly affected market activity on the stocks of the involved banks.

Although abnormal trading volumes have been observed for some banks and some trading days even before 19 January, it is only in that day (when the rumors about the government decree reached the market) that they started being observed for all the banks in the treatment group. This suggests that to properly measure the premium that the market assigns to the change in voting rights rules, one should look at cumulative abnormal returns starting two days before the event date.

As a further check, we investigate abnormal volumes for the banks in the control sample[13].

While banks in the control group are not directly affected by the reform process, the new voting structure of the banks in the treatment group may be expected to stimulate a wave of merger and acquisitions (M\&As) in the Italian banking industry, thus allowing for the possibility that other banks may indirectly be influenced by the government announcement. Indeed, some of the banks in the control group also displayed abnormal trading volumes around the event date. ISP and UCG - the two biggest banks in the country - have displayed significant abnormal volumes on the day of the announcement and the two following days (at the 5 per cent significance level), although not in the two days before the announcement. CRG, MPS and MB have been largely unaffected in terms of abnormal trading volumes. BDB, PRO and $\mathrm{CE}$, instead, have shown statistically significant abnormal trading volumes starting from two days before the announcement. Knowing that these are the three smallest banks in the control group, this suggests that the market may have anticipated their involvement in a future consolidation of the banking industry. 


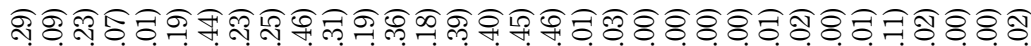

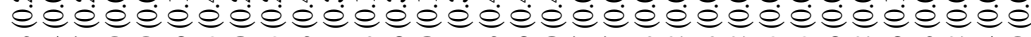
至

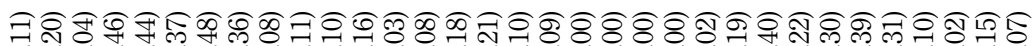

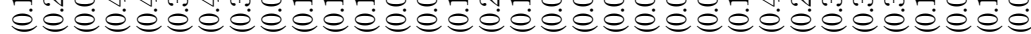

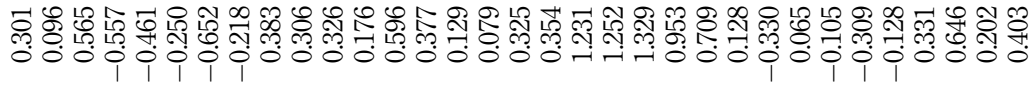

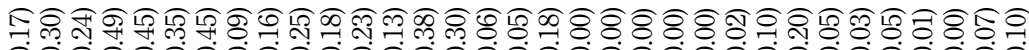

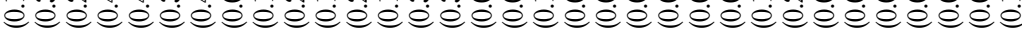

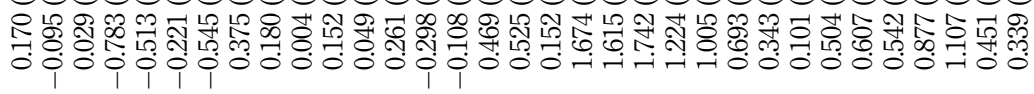

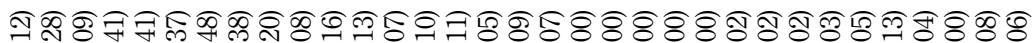

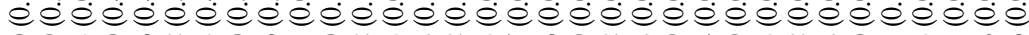

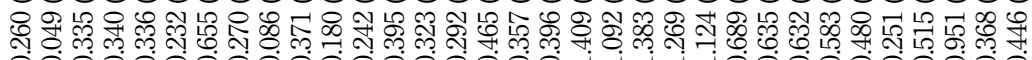

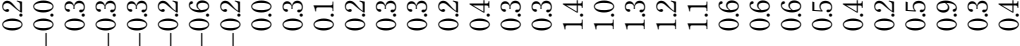

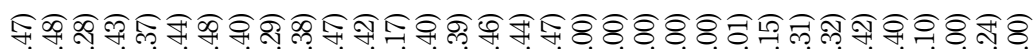

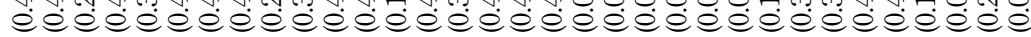

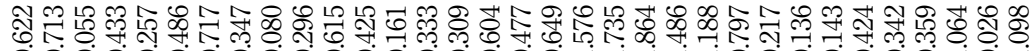

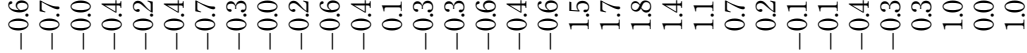

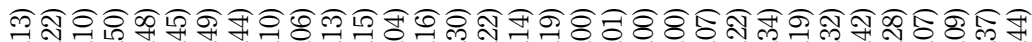

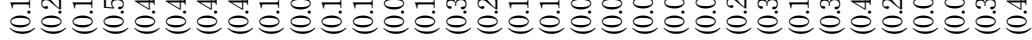

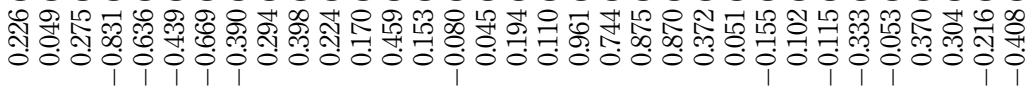

สำสำㅌํำ

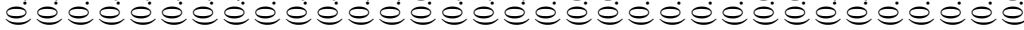

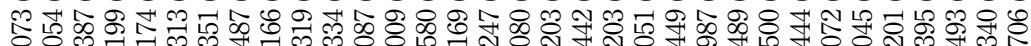

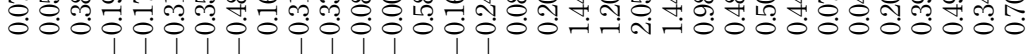

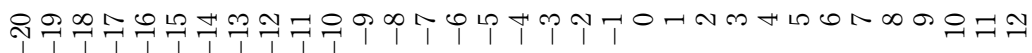

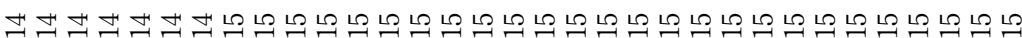

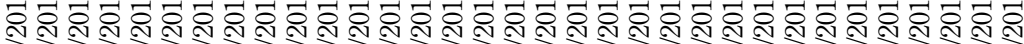

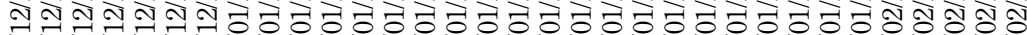
范 cooperative banks

869

Table I.

Abnormal volumes (as a percentage of floating shares) 


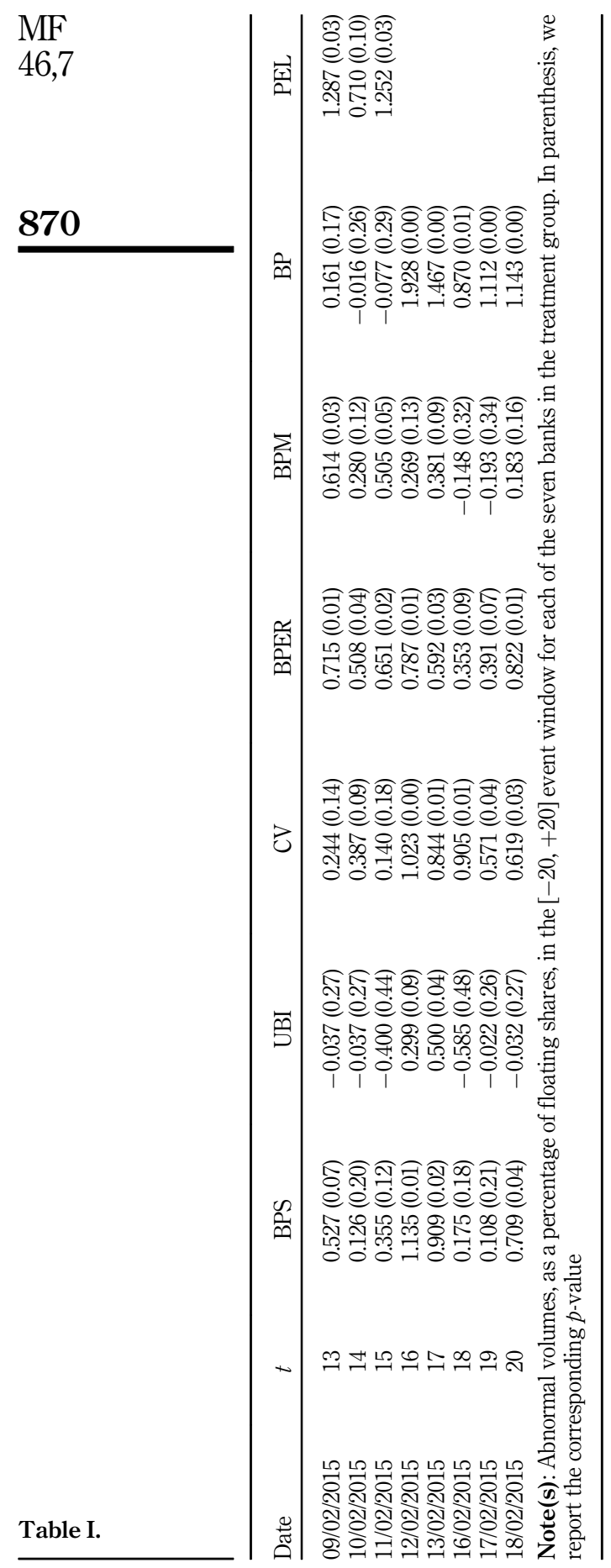


Based on these findings, in the next sections, we investigate abnormal returns in an event window starting two trading days before the government announcement, i.e. from the day in which significant abnormal volumes have been observed.

\subsection{Abnormal returns}

4.2.1 Models of normal returns. A substantial feature of an event study is the choice of an appropriate normal return model, which is then used to measure abnormal returns and to assess the impact of an event. We compute (continuously compounded) returns as the log of the ratio between prices in two consecutive trading days. This corresponds to calculating returns according to a buy-and-hold strategy, which seems more appropriate than resorting to traditional abnormal returns given that our aim is to calculate the cumulative increase in value following the government announcement.

We measure abnormal returns in a variety of ways[14]. First, we compute simple raw cumulative returns over the event window. Second, we calculate market-adjusted returns by subtracting daily market returns from each bank's corresponding daily return, and then cumulate these adjusted returns over the event window. Third, we compute abnormal returns using the so-called "market model", which relies on the following linear specification:

$$
R_{i, t}=\alpha_{i}+\beta_{i} R_{m, t}+\varepsilon_{i, t}
$$

where $R_{i, t}$ and $R_{m, t}$ are the returns on day $t$ on the shares of bank $i$ and on the market portfolio, respectively, and $i, t$ is the error term. We estimate the two parameters $\alpha$ and $\beta$ for each bank $i$ over the estimation window, using the Eurostoxx index as a proxy for market returns and regressing daily bank returns over the corresponding daily market return. By means of this model, we can measure the expected normal returns during the event window as a function of market returns. We then obtain daily abnormal returns in the event window as:

$$
\widehat{A R_{i, t}}=R_{i, t}-\widehat{\alpha}_{i}+\widehat{\beta}_{i} R_{m, t},
$$

where $\widehat{A R}_{i, t}$ are the abnormal returns for bank $i$ at time $t$. Finally, cumulative abnormal returns are obtained as the sum of daily abnormal returns. Fourth, we compute sectoradjusted abnormal returns using the procedure outlined in Eqns (2) and (3), but for the fact that the coefficients $\alpha$ and $\beta$ are now obtained by regressing daily bank returns over corresponding daily returns on a value-weighted portfolio of banks incorporated in the Euro Area[15]. Fifth, we compute normal returns by means of a three-factor model, using the factors proposed by Fama and French (1992), and then compute abnormal and cumulative abnormal returns with the same procedure described above. Finally, we use a five-factor model to describe banks' returns (FF-aug five-factor), by augmenting the FamaFrench model with two additional factors, the first measuring interest rate risk and the second measuring exchange rate risk[16]. The interest rate risk factor we consider is the spread between ten-year Italian Government Bonds and ten-year German Government Bonds, while the exchange rate risk factor is the spot Euro-US\$ exchange rate.

4.2.2 Analysis of the treatment group. We first run an event study on the seven banks in the treatment group. The first step consists in the estimation of the return models. Having obtained the needed model betas, we compute abnormal returns (ARs) and cumulative abnormal returns (CARs) over the event window for each bank with each of the models described above. Part 1 of Table II reports individual CARs for all the return models considered, over the window $[-2,+20]$, while Part 2 of Table II reports CARs for the shorter event window $[-2,+1]$. This shorter window minimises the possibility that other events affected the returns of the banks involved in the same days. In both event windows, CARs are
Voting rights in Italian cooperative banks 


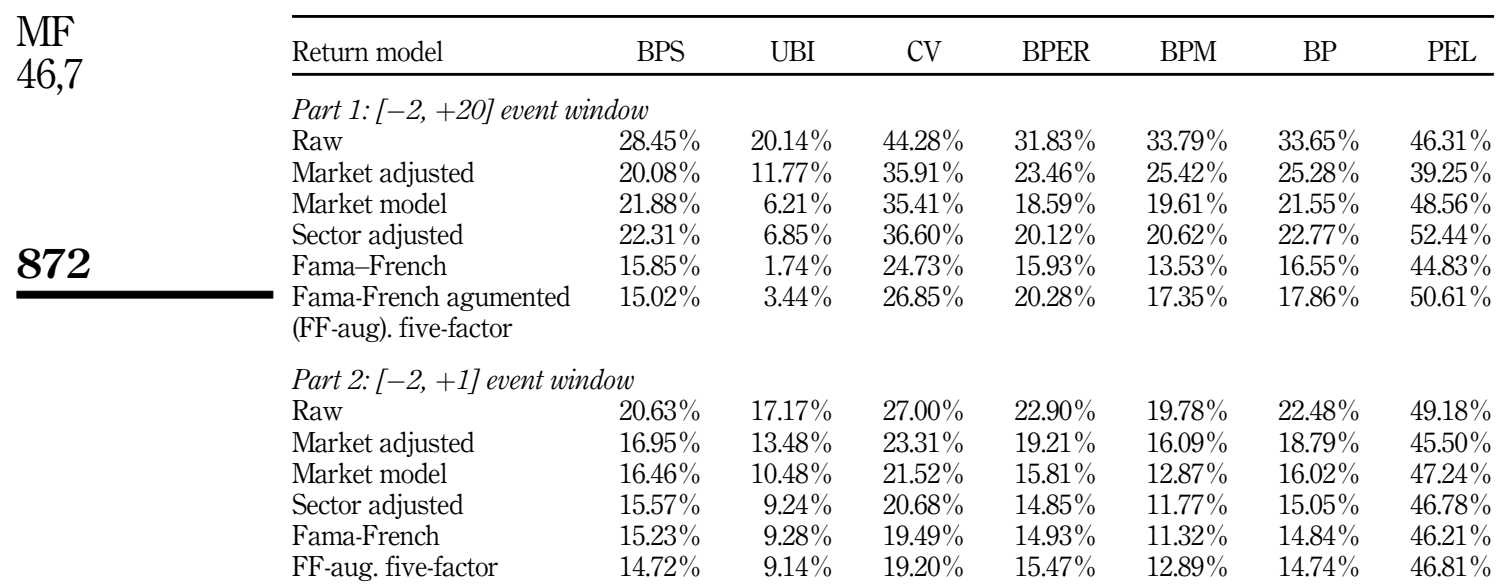

Table II. Note(s): The table reports the cumulative abnormal returns for a variety of return models for each of the seven Cumulative abnormal banks in the treatment group. Part 1 refers to a longer event window, spanning from two days before until returns over different event windows

20 days after the announcement date. Part 2 refers to a shorter event window, spanning from two days before until one day after the announcement date

statistically significant both when relying on the traditional event-study methodology and when relying on the "SQ" test proposed by Gelbach et al. (2013), which has a better performance in an event study with a limited number of firms. [Table II about here.]

For all banks, but UBI, the announcement effect is stronger in the longer event window. In the case of UBI, instead, the CAR is significantly smaller in the longer event window than in the shorter one: 3.4 per cent with the longer window vs 9.1 per cent with the shorter one, possibly because of a confounding event in the longer window. Indeed, on 11 February 2015, the $\mathrm{CEO}$ and other board members of UBI have been reported by financial newspapers to be under investigation for creating obstacles to the Bank of Italy supervision.

Given the limited size of the population we are studying, we cannot rely on regression analysis to explain what factors affect the observed CARs. We can only meaningfully discuss the correlation coefficients between our CARs and a set of bank characteristics. Table III reports, for each bank, the values of the variables we consider in this analysis. $\mathrm{CAR}_{[-2,+20]}$ and $\mathrm{CAR}_{[-2,+1]}$ are the CARs in the two event windows described above. EPS is earnings per share at the end of the 2014 fiscal year; ROE and ROIC are return on equity and return on invested capital in the 2014 fiscal year, respectively. TIER 1 is the core Tier 1 ratio at the end of 2014. We also control for banks' ownership structures. Assets is balance sheet's total assets (in EUR millions) at the end of the financial year 2014. TIER1 stressed is the level of TIER1 the bank would have in a stressed macroeconomic scenario, as estimated by the European Banking Authority 2014 EU-wide stress test. NPL (\%) is the percentage of non-performing loans (NPL) as a share of total outstanding loans. NPL coverage (\%) indicates the percentage of NPLs for which the bank has set aside provisions to cover the expected losses. Finally, NPL collateral (\%) indicates the percentage of NPLs for which the bank has received collaterals[17]. To allow for the argument (very much invoked after the decree has been approved) that equity values may increase because the change in the voting mechanism is expected to prompt a consolidation process among the interested banks by making them more "contestable", we also control for banks' ownership structure. Indeed, to the extent that this argument is correct, we should observe a larger effect on the returns of those banks where the ownership is more dispersed, as these are the banks that are more likely to be target for 


\begin{tabular}{|c|c|c|c|c|c|c|c|c|}
\hline Variable & BPS & UBI & $\mathrm{CV}$ & BPER & $\mathrm{BPM}$ & $\mathrm{BP}$ & PEL & in It \\
\hline $\mathrm{CAR}_{[-2,+20]}$ & 0.150 & 0.034 & 0.268 & 0.203 & 0.173 & 0.179 & 0.506 & cooperativ \\
\hline $\mathrm{CAR}_{[-2,+1]}$ & 0.147 & 0.091 & 0.192 & 0.155 & 0.129 & 0.147 & 0.468 & \\
\hline $\mathrm{EPS}^{[-2,+1]}$ & 0.302 & -0.806 & -0.407 & 0.041 & 0.059 & -6.502 & -0.13 & \\
\hline ROE & 5.300 & -7.210 & -22.000 & 0.330 & 5.690 & -24.020 & -29.600 & \\
\hline ROIC & 2.140 & 0.320 & -1.500 & 0.650 & 1.940 & -2.400 & -1.150 & \\
\hline TIER1 & 9.760 & 12.330 & 10.970 & 11.290 & 12.210 & 12.260 & 7.400 & 8 \\
\hline Ownership (\%) & 5.098 & 7.181 & 2.358 & 0.000 & 5.734 & 2.891 & 2.021 & \\
\hline Shareholder $1(\%)$ & 2.811 & 4.903 & 2.358 & 0.000 & 5.734 & 2.891 & 2.021 & \\
\hline Shareholder $2(\%)$ & 2.287 & 2.278 & 0.000 & 0.000 & 0.000 & 0.000 & 0.000 & \\
\hline Assets & 35.226 & 119.343 & 28.159 & 59.474 & 47.368 & 119.527 & 12.519 & \\
\hline TIER1 stressed & 4.2 & 8.2 & 3.5 & 5.2 & 4 & 4.7 & na & \\
\hline NPL $(\%)$ & 11.04 & 11.38 & na & 18.61 & 13.21 & 19.61 & na & \\
\hline NPL coverage $(\%)$ & 43.21 & 27.13 & na & 40.67 & 38.79 & 34.26 & na & \\
\hline NPL collateral (\%) & 47.00 & 54.81 & na & 48.57 & 44.89 & 57.45 & na & \\
\hline
\end{tabular}

Note(s): The table reports CARs, accounting and ownership data for each of the seven banks in the treatment group. $\mathrm{CAR}_{[-2,+20]}$ and $\mathrm{CAR}_{[-2,+1]}$ are the estimated $\mathrm{CARs}$ for the longer and shorter event window, respectively. EPS indicates earnings per Share, while ROE and ROIC are return on equity and return on invested capital, respectively. TIER1 indicates the TIER 1 ratio. Ownership is the percentage of stocks held by "significant stockholders" (i.e. investors holding more than 2 per cent of outstanding shares, based on the Consob database), while Shareholder 1 and Shareholder 2 indicate the percentage held by the first and second largest shareholder, respectively. Assets is balance sheet's total assets at the end of the financial year 2014, with values measured in EUR millions. TIER1 stressed is the estimated Tier 1 that the bank would have in a stressed macroeconomic scenario, according to the European Banking Authority 2014 EU-wide stress test. The following three variables, finally, are from the European Banking Authority 2015 EU-wide transparency exercise: NPL (\%), which measures the percentage of non-performing loans (NPL') as a share of total outstanding loans; NPL coverage (\%), which indicates the percentage of NPLs for which the bank has set aside provisions to cover the expected losses; and NPL collateral (\%), which indicates the percentage of NPLs for which the bank has received collaterals

Table III. Bank-level data

acquisitions. To check this possibility, we explicitly include ownership data among our set of individual banks' characteristics[18]. In particular, we collect data on ownership, which is defined as the share of ownership of the first two largest shareholders of each bank at the end of 2014 based on the reports filed with Consob, to whom, under Italian law, any person or institution owning 2 per cent or more of an Italian listed company must report such ownership. Furthermore, we control for the share of ownership of the largest shareholder (Shareholder 1), and for that of the second largest shareholder (Shareholder 2)[19].

As shown in Table III, banks differ both in terms of profitability and in terms of leverage. As a natural consequence of their governance structure, ownership concentration is not particularly high in any of the considered banks. Banks also differ largely in terms of size, as measured by total assets on 31 December 2014.

Table IV reports the correlation matrix among all the considered variables. There is a strong negative correlation between CARs and the Tier 1 ratio, implying that lower levels of the Tier 1 ratio are correlated with higher CARs. This is in line with expectations: the reform aims at making access to equity capital easier for these banks; hence, the market should reward more those banks that are more in need of additional equity (i.e. those with a lower Tier 1 ratio). A strong and negative correlation is also found between CARs and bank size, indicating that the market reaction has been bigger for smaller banks. The correlation is negative also when looking at profitability ratios: CARs are higher for banks with lower ROE or ROIC (although to a lower extent in the latter case). This is also consistent with expectations: the reform makes banks more "contestable" so that poor-performing managers can be more easily replaced (e.g. through a takeover) and inefficiencies in banks' operations 
MF
46,7

874

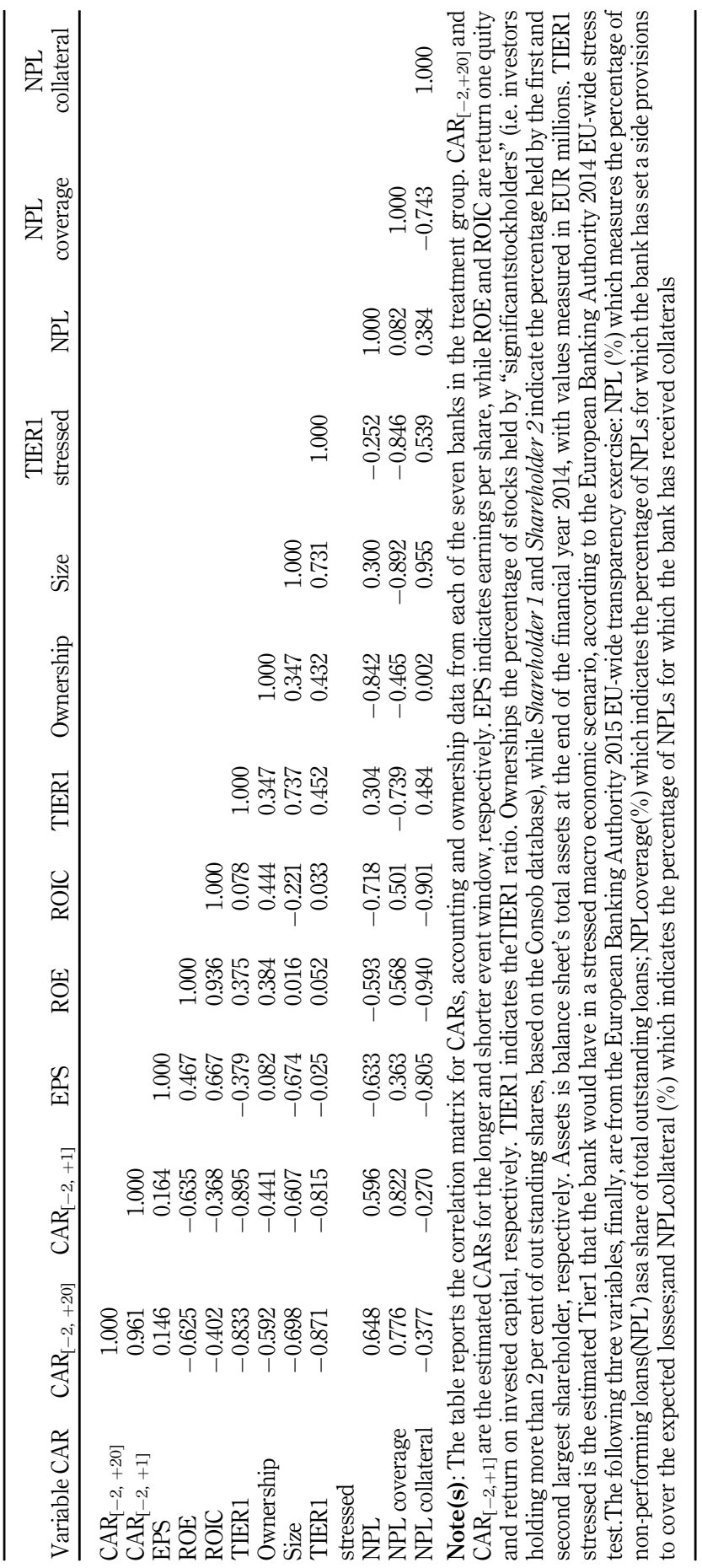

Table IV.

Correlation matrix 
eliminated to restore banks' profitability. Finally, when looking at the correlation with ownership, CARs are larger in banks characterised by lower levels of ownerships by "significant shareholders". This result is also in line with expectations: by making banks more contestable, the reform should produce stronger effects where no significant ownership exists. However, this interpretation needs to be taken cautiously, given the governance structure of the Banche Popolari. In fact, workers' union typically exercises a dominant influence in shareholders' meetings, thus conditioning the management of the bank. This is despite the lack of significant individual ownership or signed shareholders' agreements. In the parliamentary hearing cited above, the President of Consob, Mr Vegas, stressed that one of the main problems in the governance of the Banche Popolari is related to the ability of the workers' unions to coordinate their votes in shareholders' meeting, effectively controlling the bank even in the absence of official shareholders' agreements. This is especially problematic in a context of low shareholders' meeting participation (as documented again in Mr Vegas' hearing) that allows a small but well-coordinated group of shareholders to exercise a dominant influence during general meetings. Unfortunately, the lack of official disclosures about such formal or informal agreements does not allow us to estimate the existence of a correlation between the "power" of these agreements and the market reaction after the reform announcement[20].

4.2.3 Analysis of the control group. To understand whether excess returns concern exclusively the banks in the treatment group, we repeat the analysis in Sub-section 4.2.2 focusing on the control group. If similar return patterns are found for the control group, then it must be that either the event affected the banks in both groups, or that excess returns are not directly induced by the government announcement. Either way, this result would entice that we cannot use the excess returns in the treatment group as a measure of the value assigned by the market to the change in voting rights. If the returns of most of the banks in the control group remain instead unaffected, then one could confidently conclude that the excess returns observed in the treatment group reflect the higher value assigned by the market when moving from the "one head-one vote" to the "one share-one vote" system. Table V reports our findings.

\begin{tabular}{lrrrrrrrr}
\hline Return model & CRG & BDB & MPS & PRO & MB & UCG & ISP & CE \\
\hline Part 1: [-2, +20] & event window & & & & & & & \\
Raw & $1.74 \%$ & $19.93 \%$ & $14.78 \%$ & $20.43 \%$ & $17.68 \%$ & $9.40 \%$ & $14.51 \%$ & $6.97 \%$ \\
Market adjusted & $-6.63 \%$ & $11.56 \%$ & $6.41 \%$ & $12.06 \%$ & $9.31 \%$ & $1.03 \%$ & $6.14 \%$ & $-1.40 \%$ \\
Market model & $7.80 \%$ & $19.67 \%$ & $24.04 \%$ & $13.30 \%$ & $5.76 \%$ & $-3.57 \%$ & $0.01 \%$ & $-0.71 \%$ \\
Sector adjusted & $-0.42 \%$ & $15.67 \%$ & $10.33 \%$ & $4.24 \%$ & $-0.62 \%$ & $-9.92 \%$ & $-6.68 \%$ & $-6.77 \%$ \\
Fama-French & $-1.84 \%$ & $15.39 \%$ & $12.99 \%$ & $6.28 \%$ & $0.07 \%$ & $-5.17 \%$ & $-0.81 \%$ & $-8.66 \%$ \\
FF-aug. five- & $-0.65 \%$ & $17.12 \%$ & $18.27 \%$ & $12.37 \%$ & $0.26 \%$ & $-4.45 \%$ & $-1.35 \%$ & $-8.63 \%$ \\
factor & & & & & & & & \\
Part 2: [-2, +1] event window & & & & & & & \\
Raw & $7.06 \%$ & $8.91 \%$ & $11.43 \%$ & $4.97 \%$ & $7.55 \%$ & $9.49 \%$ & $4.31 \%$ & $6.45 \%$ \\
Market adjusted & $3.37 \%$ & $5.22 \%$ & $7.75 \%$ & $1.28 \%$ & $3.86 \%$ & $5.80 \%$ & $0.62 \%$ & $2.77 \%$ \\
Market model & $5.13 \%$ & $7.18 \%$ & $9.20 \%$ & $1.14 \%$ & $1.99 \%$ & $3.18 \%$ & $-2.13 \%$ & $2.64 \%$ \\
Sector adjusted & $-1.79 \%$ & $3.66 \%$ & $-1.61 \%$ & $-6.04 \%$ & $-4.13 \%$ & $-3.30 \%$ & $-8.74 \%$ & $-2.64 \%$ \\
Fama-French & $3.57 \%$ & $6.39 \%$ & $7.16 \%$ & $0.00 \%$ & $0.83 \%$ & $2.57 \%$ & $-2.62 \%$ & $1.04 \%$ \\
FF-aug. five- & $4.19 \%$ & $6.76 \%$ & $6.66 \%$ & $-0.19 \%$ & $0.87 \%$ & $2.31 \%$ & $-2.87 \%$ & $1.36 \%$ \\
factor & & & & & & & &
\end{tabular}

Note(s): The table reports the CARs for a variety of return models for each of the eight banks in the control group. Part 1 refers to a longer event window, spanning from two days before until 20 days after the announcement date. Part 2 refers to a shorter event window, spanning from two days before until one day after the announcement date
Voting rights in Italian cooperative banks 


\begin{tabular}{llcccccccc} 
MF & Variable & CRG & BDB & MPS & PRO & MB & UCG & ISP & CE \\
\cline { 2 - 9 } 46,7 & CAR $_{[-2,+20]}$ & -0.006 & 0.171 & 0.183 & 0.124 & 0.003 & -0.044 & -0.013 & -0.086 \\
& CAR & 0.042 & 0.068 & 0.067 & -0.002 & 0.009 & 0.023 & -0.029 & 0.014 \\
& EPS & -2.723 & 0.312 & -8.077 & 0.005 & 0.55 & 0.35 & 0.076 & 0.458 \\
& ROE & -32.43 & 4.88 & -88.27 & 2.34 & 6.28 & 4.26 & 2.8 & 6.7 \\
& ROIC & -1.6 & 1.89 & -4.18 & 0.67 & 2.9 & 1.52 & 1.28 & 1.8 \\
$\mathbf{8 7 6}$ & TIER1 ratio & 8.7 & 10.46 & 8.67 & 26.1 & 11.08 & 11.12 & 14.2 & 11.12 \\
& Assets & 37.312 & 12.366 & 177.757 & 1.896 & 69.753 & 829.918 & 635.017 & 34.606 \\
& Ownership & 0.336 & 0.672 & 0.102 & 0.593 & 0.187 & 0.13 & 0.196 & 0.769 \\
& Shareholder 1 & $19.00 \%$ & $51.60 \%$ & $4.50 \%$ & $53.50 \%$ & $8.70 \%$ & $6.50 \%$ & $9.90 \%$ & $76.90 \%$ \\
& Shareholder 2 & $10.00 \%$ & $7.90 \%$ & $3.20 \%$ & $3.80 \%$ & $5.00 \%$ & $3.50 \%$ & $5.00 \%$ & $0.00 \%$ \\
& TIER1 stressed & -2.4 & - & -0.1 & - & 6.2 & 6.8 & 8.3 & 8.9 \\
& NPL (\%) & 21.72 & na & 26.24 & na & 4.65 & 11.52 & 13.88 & 4.66 \\
& NPL coverage & 40.92 & na & 48.97 & na & 49.04 & 51.30 & 46.79 & 40.70 \\
& (\%) & & & & & & & & \\
& NPL collateral & 48.41 & na & 41.76 & na & 30.19 & 29.94 & 38.37 & 50.45 \\
& (\%) & & & & & & & &
\end{tabular}

Note(s): The table reports CARs, accounting and ownership data for each of the eight banks in the control group. $\mathrm{CAR}_{[-2,+20]}$ and $\mathrm{CAR}_{[-2,+1]}$ are the estimated CARs for the longer and shorter event window, respectively. EPS indicates earnings per Share, while ROE and ROIC are return on equity and return on invested capital, respectively. TIER 1 indicates the Tier 1 ratio. Ownership is the percentage of stocks held by "significant stockholders" (i.e. investors holding more than 2 per cent of outstanding shares, based on the Consob database), while Shareholder 1 and Shareholder 2 indicate the percentage held by the first and second largest shareholder, respectively. Assets is balance sheet's total assets at the end of the financial year 2014, with values measured in EUR millions. TIER1 stressed is the estimated Tier 1 that the bank would have in a stressed macroeconomic scenario, according to the European Banking Authority 2014 EU-wide stress test. The following three variables, finally, are from the European Banking Authority 2015 EU-wide transparency exercise: NPL (\%), which measures the percentage of non-performing loans (NPL') as a share of total

Table VI.

Bank-level data, control group outstanding loans; NPL coverage (\%), which indicates the percentage of NPLs for which the bank has set aside provisions to cover the expected losses; and NPL collateral (\%), which indicates the percentage of NPLs for which the bank has received collaterals

In the longer event window, as shown in Part 1 of Table V, BDB and MPS have large CARs (17.1 and 18.3 per cent, respectively), as well as PRO (12.4 per cent), which instead has a CAR of -0.2 per cent in the shorter event window. All other banks have either zero or negative CARs. In particular, no increase in value is observed for the two largest Italian banks: UCG and ISP. As for the reaction of BDB and MPS returns to the announcement of the reform, it may be explained based on their characteristics, which are summarised in Table VI.

MPS has long been suffering due to cumulated losses, financial weaknesses and low profitability. Given that the government reform is expected to prompt a new wave of consolidation in the Italian banking industry, there are reasons to believe that MPS will take part in it, as a potential aggregation with one of the banks directly involved with the reform is largely seen as being mutually beneficial. Similar considerations, although for different reasons, apply to $\mathrm{BDB}$, which is a relatively small bank operating mainly in northern Italy that the market may see as a likely candidate for aggregating with one of the banks in the treatment group. In the case of $\mathrm{PRO}$, the large cumulative return may depend on the small size of the bank, jointly with the large fraction of equity held by the first shareholder (53.5 per cent), that may affect the liquidity of the stock in the market. Looking at the shorter event window, the results in Part 2 of Table V show that only CRG, BDB and MPS have excess returns of an economically relevant magnitude (4.2, 6.8 and 6.7 per cent, respectively, when considering the five-factor model). All other banks have much smaller cumulative abnormal returns. While the abnormal return for BDB and MPS is significant also in the longer window, 
as already discussed, in the case of CRG, instead, the effect observed is completely reabsorbed in the longer time span, when it becomes not significant. But for these exceptions, overall, the effect of the government announcement on CARs has been confined within the treatment group.

Voting rights in Italian cooperative banks

\section{A Bayesian structural time-series analysis}

In this section, we investigate the causal impact of the reform announcement on stock prices

by adopting the Bayesian methodology proposed by Brodersen et al. (2015). This methodology allows to infer the causal impact generated by the government announcement on the equity value of the banks involved. This is achieved by explicitly modelling how the time series of stock returns would have evolved without the intervention through the generation of a synthetic counterfactual that combines a number of potential predictors into a single "synthetic control". As in the previous section, we first focus on each of the individual banks involved in the reform process, and then on each of the banks in the control group.

Our set of potential predictors includes a list of routinely computed stock market indexes: the Eurostoxx ex-banks, the Eurostoxx Large-cap ex-banks, the Eurostoxx50 ex-banks, the Eurostoxx 50, the Eurostoxx $5060 D$ Volatility, the Datastream Italy ex-banks, the NYSE composite, the Nasdaq composite, the Stoxx Emerging Markets TMI, the Stoxx Emerging Markets 50, the Stoxx Emerging Market TMI small cap, the value-weighted index of European banks described in the previous Section, the yield spread between the ten-year Italian BTP and the German Bund and the US\$-Euro exchange rate. Table VII reports our findings when using both the $[-2,+20]$ and the $[-2,+1]$ event windows.

Summing the individual data points during the post-intervention period, the actual overall value of the response variable is reported in the row labeled as cumulative. By contrast, had the intervention not taken place, our model predicts an expected value corresponding to the figure reported in the row predicted. The row absolute is obtained as the difference between the actual and the predicted value, and it represents the estimate of the cumulative effect produced by the event on stock returns. The row probability reports the posterior probability of a causal effect. It corresponds to the probability that the absolute effect is a consequence of the event. Alternatively, one minus the values in the row probability represents the Bayesian tail-area probability, i.e. the probability that the absolute effect is obtained by chance. Adopting the usual significance levels, this probability can immediately be used to determine whether the causal effect can be considered statistically significant or not.

Over the longer event window $[-2,+20]$ - see Part 1 of Table VII - the effect is statistically significant at the 5 per cent level for $\mathrm{CV}$, and at the 1 per cent level for PEL, while it is not significant for BPS, UBI, BPER, BPM and BP. PEL shows an extremely large absolute value: the increase in equity value is close to 51 per cent in the 15 trading days following the announcement, after which it was then suspended from trading. CV has an absolute value of about 22 per cent. UBI shows a negative effect, which, however, is not statistically significant. The effects on BPS, BPER, BPM and BP range between 6 and 14 per cent, but in all cases, they are not statistically significant.

Part 2 of Table VII reports our findings for the event window $[-2,+1]$. In this shorter event window, the probability that the observed cumulative excess returns are generated by chance is below 1 per cent in all cases so that the causal effect can be considered statistically significant for all banks. The measured impact varies largely in the group. Again, PEL is the bank with the highest effect ( 46 per cent), more than twice the estimated effect of 18.3 per cent for the second bank in the group, CV. UBI has, instead, the smallest value, with an estimated impact of 7 per cent, while the impact for BPS, BPER, BPM and BP ranges between 9.8 and 13.9 per cent. The average absolute effect is around 13 per cent when excluding PEL, the price 


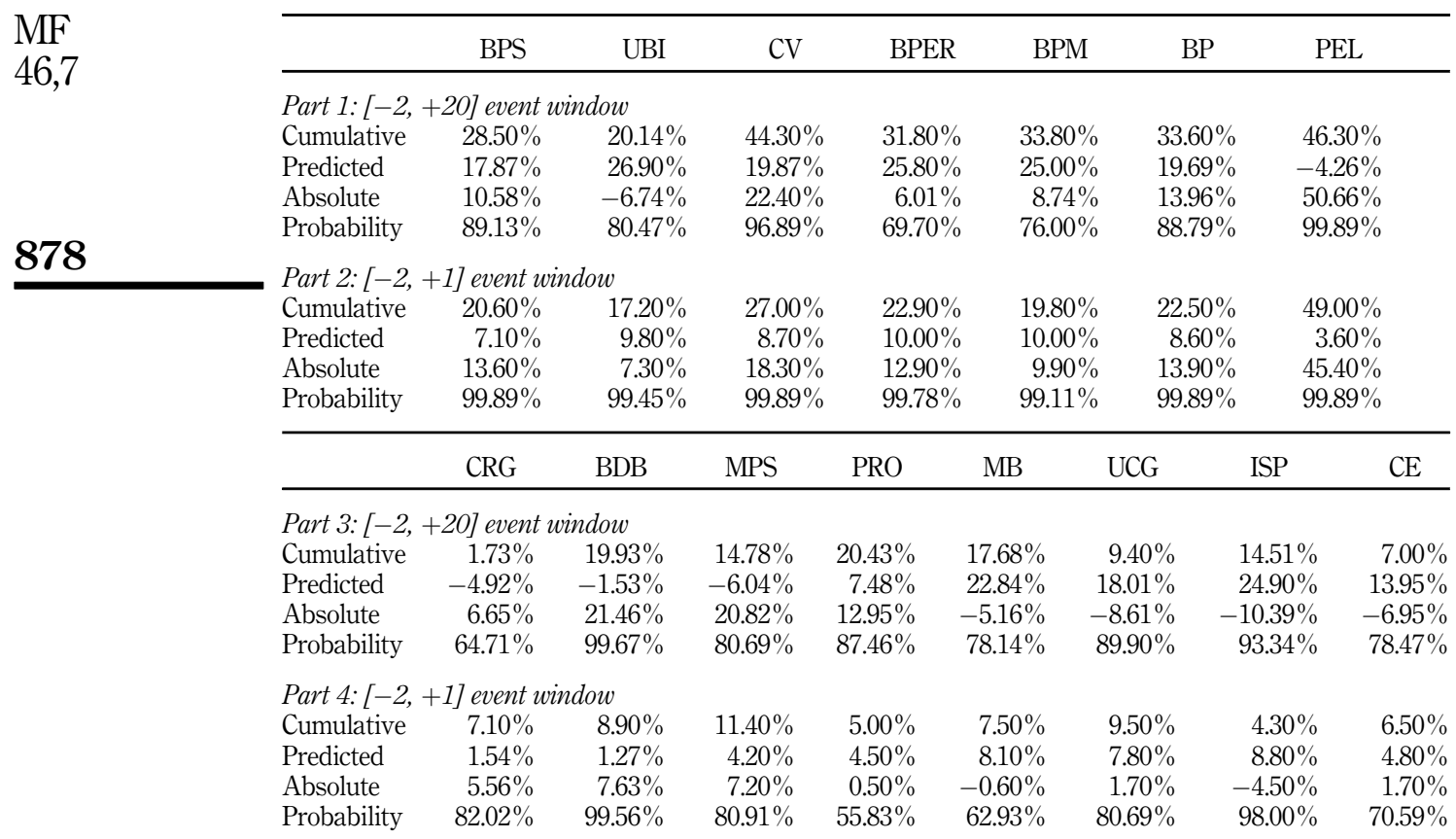

Note(s): The table reports the estimated causal impact for each of the seven banks in the treatment group (Parts 1-2) and each of the eight banks in the control group (Parts 3-4). Parts 1 and 3 refer to the longer event window, spanning from two days before until 20 days after the announcement date. Parts 2 and 4 refer to the shorter event window, spanning from two days before until one day after the announcement date. Cumulative indicates the actual, cumulative returns over the event window. Predicted indicates the cumulative returns predicted by the statistical model. Absolute is the estimated impact induced by the announcement, obtained as the difference between the actual and predicted returns. Probability indicates the posterior probability of a causal effect

Table VII.

Causal impact over different event windows reaction of which is amplified by the concurring events that will ultimately lead to the bank's bail-in.

We then repeat the analysis for the banks in the control group, using the same set of variables to obtain counterfactual predictions. Parts 3 and 4 of Table VII report our findings.

Overall, the Bayesian analysis for the control group suggests that the government announcement did not affect these banks, neither in the longer nor in the shorter event window. Indeed, the hypothesis that the abnormal return is obtained by chance can be rejected at the 1 per cent level only for $\mathrm{BDB}$, both in the shorter and in the longer event window. In both cases, the cumulative absolute effect is positive, indicating that the event induced an increase in returns. As already noted in the previous section, such positive effect may indicate that, following the reform, this small bank was seen as a natural candidate for aggregation[21].

\section{Concluding remarks}

The market reaction to the announcement of a reform transforming the voting rights of Banche Popolari from a "one head-one vote" to a "one share-one vote" mechanism has been both statistically and economically significant. The behavior of the stock returns of a "control 
group" of banks in the same time interval shows that the changes observed in the stock returns of the Banche Popolari can be confidently attributed to the government announcement rather than to other contemporaneous events.

Excluding the Banca Popolare dellEtruria e del Lazio, which is to a large extent an outlier, the six remaining publicly listed Banche Popolari experienced cumulative abnormal returns in the $[-2,+1]$ event windows between 9 and 19 per cent based on our event studies, and between 7 and 18 per cent based on our Bayesian analysis. The market assessment of the value of a change in the voting rights mechanism is smaller than the one usually found by the literature focusing on the price discrepancies between different categories of stocks in dualclass companies. At the same time, we estimate a value that is much greater than that found by Kind and Poltera (2013) who quantify it by looking at the price of American call options in relation to that of the underlying stock.

Interestingly, we find a negative relationship between size and observed abnormal returns. This suggests that the market sees smaller banks as good candidates for aggregations that could make them both more financially viable and more efficient. Furthermore, we also find a negative correlation between the level of the TIER 1 ratio and the observed abnormal returns. Consistent with one of the stated goals of the reform, this fits well with the idea that market expects the banks characterised by lower TIER 1 ratios to gain easier and larger access to equity capital as a consequence of the change in the allocation of voting rights.

\section{Notes}

1. See Leibenstein (1966) for a careful investigation of the concept of "X-Efficiency".

2. See, e.g. Fisch (2015) on the use of event studies by the US Supreme Court.

3. Consob (Commissione Nazionale per le Società la Borsa) is the Italian authority responsible for regulating the securities market.

4. Two of these banks, BPVI and VB, dissolved in the years following the reform, despite their transformation into joint-stock companies. More precisely, after suffering losses that eroded their entire capital, both BPVI and VB-although transformed into joint-stock companies as required by the reform - failed to raise the required capital to restore the prescribed solvency ratios. Following a failed attempt to merge the two banks, eventually both of them have been declared insolvent by the European Central Bank on 23 June 2017. They have then been split into good and bad banks by the Italian Government, with the two resulting good banks sold to Intesa Sanpaolo for a symbolic price of $€ 0.50$ each.

5. On the 18 October 2016 Consob - the Italian market authority - issued Communication 0092492/ 2018, recommending issuers of unlisted financial instruments (and banks in particular) to distribute them through regulated markets, or multilateral trading facilities, rather than through the traditional self-placement mechanism, which did not ensure the required transparency and fair prices. As a result, since 2017, a significant number of banks have adhered to HI-MTF - an Italian multilateral trading facility - to have their shares regularly traded and priced. Unfortunately, the relevant prices time series start only two years after the regulatory change under examination.

6. More precisely, we include: Banca Carige ("CRG”), Banco di Desio e della Brianza ("BDB”), Banca Monte dei Paschi di Siena ("MPS"), Banca Profilo ("PRO”), Mediobanca ("MB"), Unicredit ("UCG”), Intesa Sanpaolo ("ISP") and Credito Emiliano ("CE"). The only listed banks that are excluded from the control group are Banca Fineco - as it started trading just before the beginning of our estimation window (in July 2014), and it may, therefore, suffer from anomalous post-IPO trading activity, and Banca Finnat and Banca Intermobiliare - because they operate exclusively in the field of wealth management.

7. See the official press release on the Italian Government website at http://www.governo.it/articolo/ comunicato-stampa-del-consiglio-dei-ministri-n45-sistema-bancario-e-investimenti/1068 (retrieved on 8 April 2019).

8. See http://it.reuters.com/article/idITL6N0UY1O420150119 (retrieved on 7 April 2019).
Voting rights in Italian cooperative banks 
$\mathrm{MF}$

46,7

880
9. See the transcript of Mr Vegas' hearing at http:/www.consob.it/main/documenti/Pubblicazioni/ Audizioni/audizione_vegas_20150211.htm (retrieved on 8 April 2019).

10. The bank has been "resolved" months later (with the Decree 183/2015 of 22 November 2015) under the bail-in scheme introduced in the Italian legislation with Decree 180/2015, implementing the European Directive 59/2014 aimed at establishing a framework for the recovery and resolution of credit institutions and investment firms ('Bank Recovery and Resolution Directive').

11. For a deeper analysis of the reforms that involved the Italian banking sector, see the report of the Italian Treasury, available at http://www.mef.gov.it/focus/sistema_bancario/ITALIAN_BANKIN G_SECTOR.pdf (retrieved on 18 October 2019).

12. See Karafiath (2009) for a thorough review of event study methodologies aimed at identifying abnormal volumes.

13. The full results are available from the authors upon request.

14. For a comprehensive review of event study methodologies, see MacKinlay (1997).

15. This index is created with the following rules. First, the bank is incorporated in a Euro-area country. Second, it is listed during the event window. Third, it is liquid: we consider illiquid any bank for which we do not observe any price changes for an entire trading week. Finally, we exclude the italian Banche Popolari comprised in our treatment group.

16. Several authors have proposed multi-factor models for banks' returns by augmenting the FamaFrench model with factors related to interest rate and exchange rate risk. See, e.g. Flannery and James (1984) and Choi et al. (1992).

17. The last three variables are from the European Banking Authority 2015 EU-wide transparency exercise, while - as already noted - all other variables are computed or retrieved from Datastream.

18. We collect ownership and accounting data at the closing date of the 2014 financial year, which corresponds to 31 December for all banks. Accounting data for PEL are from the 2014 half-year report - 30 June 2014- because the annual financial reports for 2014 are not available. Recall that PEL has been "resolved" in February 2015 under the EU bail-in scheme.

19. For none of these banks, there exists a third shareholder with ownership greater than 2 per cent in the Consob database at the date of 31 December 2014. A value of zero for Shareholder 1 or Shareholder 2 indicates that no significant ownership is reported in the Consob database.

20. See pages 3 and 4 of the minutes of the hearings by Consob president, where it is noted that "Shareholders Associations" are officially established for helping to preserve the mutualistic nature of a Banca Popolare, but effectively used to influence the outcomes of shareholders' meetings.

21. We also observe a negative cumulative effect (significant at the 5 percent level) for ISP, which is, however, likely to be due to contemporaneous events independent of the voting rights reform. Indeed, on 12 January 2015, Reuters reported that one of ISP institutional shareholders was considering to sell a 3.25 per cent stake in the bank. Furthermore, on 29 January 2015, HSBC downgraded ISP with a 5.5 per cent cut in the target price. Finally, on 10 February 2015, FactSet reported that the disclosed results for $\mathrm{Q} 4$ have been below expectations.

\section{References}

Abadie, A. and Gardeazabal, J. (2003), "The economic costs of conflict: a case study of the Basque country", The American Economic Review, Vol. 93, pp. 113-132.

Adams, R. and Ferreira, D. (2007), "One share-one vote: the empirical evidence", Review of Finance, Vol. 12, pp. 51-91.

Brodersen, K.H., Gallusser, F., Koehler, J., Remy, N. and Scott, S.L. (2015), "Inferring causal impact using bayesian structural time-series models", The Annals of Applied Statistics, Vol. 9, pp. 247-274.

Burkart, M. and Lee, S. (2007), "One share - one vote: the theory", Review of Finance, Vol. 12, pp. 1-49. 
Casu, B. and Molyneux, P. (2003), "A comparative study of efficiency in European banking”, Applied Economics, Vol. 35, pp. 1865-1876.

Choi, J.J., Elyasiani, E. and Kopecky, K.J. (1992), "The sensitivity of bank stock returns to market, interest and exchange rate risks", Journal of Banking and Finance, Vol. 16, pp. 983-1004.

Dyck, A. and Zingales, L. (2004), "Private benefits of control: an international comparison", The Journal of Finance, Vol. 59, pp. 537-600.

Fama, E.F. and French, K.R. (1992), "The cross-section of expected stock returns", The Journal of Finance, Vol. 47, p. 427.

Ferri, G., Kalmi, P. and Kerola, E. (2014a), "Does bank ownership affect lending behavior? Evidence from the Euro area", Journal of Banking and Finance, Vol. 48, pp. 194-209.

Ferri, G., Kalmi, P. and Kerola, E. (2014b), "Organizational structure and exposure to crisis among European banks: evidence from rating changes”, Journal of Entrepreneurial and Organizational Diversity, Vol. 3, pp. 35-55.

Ferri, G., Kalmi, P. and Kerola, E. (2015), "Organizational structure and performance in European banks: a reassessment", Advances in the Economic Analysis of Participatory \& Labor-Managed Firms, Emerald Group Publishing, Vol. 16, pp. 109-141, available at: https://doi.org/10.1108/ S0885-333920150000016011.

Fisch, J.E. (2015), “The future of price distortion in federal securities fraud litigation”, Duke Journal of Constitutional Law and Public Policy, Vol. 10, pp. 87-103.

Flannery, M.J. and James, C.M. (1984), "The effect of interest rate changes on the common stock returns of financial institutions", The Journal of Finance, Vol. 39, p. 1141.

Gelbach, J.B., Helland, E. and Klick, J. (2013), "Valid inference in single-firm, single-event studies", American Law and Economics Review, Vol. 15, pp. 495-541.

Girardone, C., Molyneux, P. and Gardener, E.P.M. (2004), "Analysing the determinants of bank efficiency: the case of Italian banks", Applied Economics, Vol. 36, pp. 215-227.

Gorton, G. and Schmid, F. (1999), “Corporate governance, ownership dispersion and efficiency: empirical evidence from Austrian cooperative banking”, Journal of Corporate Finance, Vol. 5, pp. 119-140.

Harris, M. and Raviv, A. (1988), "Corporate control contests and capital structure", Journal of Financial Economics, Vol. 20, pp. 55-86.

Iannotta, G., Nocera, G. and Sironi, A. (2007), "Ownership structure, risk and performance in the European banking industry", Journal of Banking and Finance, Vol. 31, pp. 2127-2149.

Karafiath, I. (2009), "Detecting cumulative abnormal volume: a comparison of event study methods", Applied Economics Letters, Vol. 16, pp. 797-802.

Kind, A. and Poltera, M. (2013), "The value of corporate voting rights embedded in option prices", Journal of Corporate Finance, Vol. 22, pp. 16-34.

Leibenstein, H. (1966), “Allocative efficiency vs 'X-efficiency”, The American Economic Review, Vol. 56, pp. 392-415.

Levy, H. (1983), "Economic evaluation of voting power of common stock", The Journal of Finance, Vol. 38, pp. 79-93.

MacKinlay, A.C. (1997), "Event studies in economics and finance", Journal of Economic Literature, Vol. 35, pp. 13-39.

Morck, R., Wolfenzon, D. and Yeung, B. (2005), "Corporate governance, economic entrenchment, and growth", Journal of Economic Literature, Vol. 43, pp. 655-720.

Nenova, T. (2003), "The value of corporate voting rights and control: a cross-country analysis", Journal of Financial Economics, Vol. 68, pp. 325-351.

Schmid, M.M. (2009), "Ownership structure and the separation of voting and cash flow rights evidence from Switzerland”, Applied Financial Economics, Vol. 19, pp. 1453-1476.
Voting rights in Italian cooperative banks 
$\mathrm{MF}$

46,7

882
Sharpe, I.G. (1991), "Building society ownership structure and capital management", Applied Financial Economics, Vol. 1, pp. 71-78.

Thomsen, S., Pedersen, T. and Kvist, H.K. (2006), "Blockholder ownership: effects on firm value in market and control based governance systems", Journal of Corporate Finance, Vol. 12, pp. 246-269.

Zingales, L. (1994), "The value of the voting right: a study of the milan stock exchange experience", Review of Financial Studies, Vol. 7, pp. 125-148.

\section{Corresponding author}

Marco Botta can be contacted at: marco.botta@unicatt.it

For instructions on how to order reprints of this article, please visit our website: www.emeraldgrouppublishing.com/licensing/reprints.htm Or contact us for further details: permissions@emeraldinsight.com 